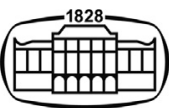

AKADÉMIAI KIADÓ

\title{
Assessment of pressure ulcers in physically handicapped patients
}

\author{
J. NEUGEBAUER ${ }^{* \dagger} \odot$ and V. TÓTHOVÁ
}

\section{Developments in Health Sciences}

$3(2020) 2,25-32$

DOI:

$10.1556 / 2066.2020 .00006$

(c) 2020 The Author(s)

\section{REVIEW ARTICLE}

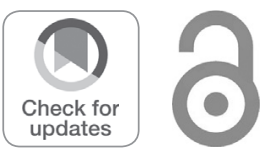

${ }^{\dagger}$ Address: Vajgar 570, 377 01, Jindrichuv Hradec, Czech Republic.

*Corresponding author. Department of Nursing, Midwifery and Emergency Care, Faculty of Health and Social Sciences, University of South Bohemia, J. Boreckeho 1167/27, 370 11, Ceske Budejovice, Czech Republic.

E-mail: neugebauer@zsf.jcu.cz
Department of Nursing, Midwifery and Emergency Care, Faculty of Health and Social Sciences, University of South Bohemia, Ceske Budejovice, Czech Republic

Received: May 27, 2019 • Revised manuscript received: March 11, 2020 • Accepted: March 16, 2020 Published online: September 5, 2020

\begin{abstract}
Purpose: Assessment of pressure ulcers is an indicator of nursing care quality. In physically handicapped patients, the risk is elevated, due to the neuropathy and incontinence that frequently accompany paresis and paralysis. We conducted a systematic review of 4 assessment scales to assess their use and usefulness for these patients. Materials/methods: We searched 5 databases for articles published between 2016 and 2018 that included terms related to the risk of pressure ulcers in physically handicapped patients, including the names of 4 assessment scales (Norton, Braden, Waterlow and Spinal Cord Injury Pressure Ulcer Scale). One hundred and three sources were returned, from which we selected 10 . We also selected an earlier source, for a total of 11. Results: The Braden and Waterlow scales are popular in clinical practice. The Norton scale is used for scientific comparisons and in clinical practice only sporadically. Expert opinion suggests that acceptance of the Spinal Cord Injury Pressure Ulcer Scale could reduce the incidence of pressure ulcers in physically handicapped patients. Conclusions: Introduction of a scale designed for handicapped patients, combined with better preventive measures, could result in the bedsore reduction of pressure ulcers. Research testing the effectiveness of the Spinal Cord Injury Pressure Ulcer Scale in the Czech population is needed to validate its use in clinical practice.
\end{abstract}

\section{KEYWORDS}

nursing, physical handicap, bedsores (pressure ulcers), evaluation tools

\section{INTRODUCTION}

Physical handicap is a widespread phenomenon, and various sorts can be imagined. The term includes patients with temporary damage to the locomotive system and those fully dependent on the help of others. On what is the physical handicap definition generally based? It can include any pathological changes in the locomotive system that limit the physiological functions of bones, joints, muscles, or tendons [1] or that limit the mobility necessary for everyday activities [2]. Several authors define the physical handicap as a disorder of the locomotive system, including the vascular and nervous supply [3], that is reflected by obvious changes in the personality [4]. Since a physical handicap is reflected in all areas of human interactions, the multidisciplinary cooperation of traumatologists, orthopaedists, urologists, sexologists, physiotherapists, and other nursing-care specialists is recommended [5].

Results of various studies suggest that factors reflected in the life of handicapped patients need to be monitored. How can the importance of individual factors be correctly assessed, and which of them need to be handled as a priority?

A physical handicap is a psychological burden, particularly if damage to the locomotive system is a result of trauma or an acute condition [6]. During emergency care, there is a high incidence of pressure ulcers because of the paresis caused neurological changes [7]. In cases of paresis, incontinence is almost always present, and the urinary bladder is catheterized at various intervals [8]. Repeated catheterization leads to infections of the urinary tract, which cause incontinence in spite of the catheterization, and, as a result, the development of 
pressure ulcers [9]. This is, among others, is the reason why a physical handicap should be regarded as a predictor of pressure ulcers [7-9].

Is goal-directed monitoring of all the needs, risks, and possible complications in physically handicapped patients possible? They need psychological support from professionals who are aware of the fact that a physical handicap results in functional and organ changes and the case of insufficient psychological support, the manifestations of social isolation or separation are more likely [10]. Psychological support is an integral part of nursing, and sufficiently qualified nurses should be able to apply the principles of assertive and pro-social behaviours. However, it is questionable whether the application of familiar methods will facilitate communication with physically handicapped patients. Because of their isolation, these patients have both a different order of priorities and a different spectrum of needs [11]. Therefore, the healthcare professional's efforts should include preventive measures, particularly measures to diminish the risk of pressure ulcers, to train the patient in self-service activities, and to harmonize the patient's mental and somatic states [12].

Since a physical handicap is multidisciplinary, critical questions need to be asked in a goal-oriented way, and individual needs need to be addressed separately; but in the end, what the patient needs most is holistic nursing care. For example, in physically handicapped patients, paralysis often causes insensitivity to painful stimuli, which causes frequent hospitalizations or the occurrence of complications. What are the right steps to remove this threat so that patients can concentrate on other necessary activities such as self-service training?

Several scales for assessing the risk of pressure ulcers have been developed and further modified, but the most common is the Norton, Braden, and Waterlow scales [13], all of which were studied for their predictive validity in Czech long-term care facilities [14]. Five weeks after admission in 2014, there was a $13 \%$ incidence of pressure ulcers in patients not screened for being handicapped, corresponding with the $12.87 \%$ recorded by the Czech Ministry of Health for 2008. The Norton scale was found to be the best predictor.

In Czech nursing, as well as worldwide, the incidence of pressure ulcers has been rapidly decreasing. For example a French study reports a decrease in the incidence of pressure ulcers in handicapped patients from $75 \%$ to $55 \%$ in just the course of the study [15].

The described scales record the basic risk factors of pressure ulcer development, but are they sufficiently prospective for physically handicapped patients, who have functional and organ changes, neurological deficits, and unusual needs? This question was dealt with by experts abroad who, in 1996, described a new scale called SCIPUS (Spinal Cord Injury Pressure Ulcer Scale). It contains additional factors, such as the degree of the handicap, blood tests, and concomitant diseases [16]. According to Mortenson and Miller, SCIPUS should be sufficiently prospective for the assessment of pressure ulcer development in both emergency and chronic care
[17]. The subcategories of concomitant diseases (where pulmonary and heart diseases or autonomic dysreflexia are included) and blood tests measuring albumin, creatine, and glucose are particularly contributive for physically handicapped patients. The scale is recommended in acute care, particularly for 2- or 3-day registration of risk factors in patients with spinal cord damage and other traumas leading to a physical handicap [18]. The scale was compared with the Norton, Braden, Hosnell, and Waterlow scales, and the results showed that SCIPUS had a higher level of data complexity. However, at standard clinics, its use is rather unpractical and expensive [17].

The scales assessing the development of pressure ulcers have been modified several times. In the Czech Republic, the Braden scale, a modified Norton scale, and, sporadically, the Waterlow scale are used [14]. The assessments are sufficiently effective for patients without any physical handicap. However, in physically handicapped patients, some additional risk factors for these patients need to be added. Further studies, validation of the scale, or practical examples from Czech healthcare should support the data from foreign studies.

\section{Purpose}

We conducted a systematic review of the Norton, Braden, Waterlow, and SCIPUS scales to assess their use and usefulness for physically handicapped patients.

\section{MATERIAL AND METHODS}

The data were found in the EBSCO, PubMed, Scopus, Science Direct, and Web of Science databases between January 2016 and October 2018. The criteria were set for sources on assessing the risk of pressure ulcer development in patients with a physical handicap. We used the following keywords: physical handicap/physical disability, Waterlow scale, Braden scale, Norton scale, SCIPUS (Spinal Cord Injury Pressure Ulcer Scale), pressure ulcer assessment and nursing.

We found 103 articles in 5 databases. Twentyseven were in EBSCO, 31 in Scopus, 18 in Science Direct, 11 in Web of Science, and 16 in Pubmed. Based on our analysis of the abstracts, 68 articles were excluded. Thirtyfive were chosen for the analyses of the full texts. From these, 10 articles which met our criteria were chosen. Because of the shortage of information on the SCIPUS scale, a relevant older source was chosen. In total, 11 articles were chosen for detailed analysis (Fig. 1).

To assess the selected scales (Table 1), we used individual criteria based on the data of Anderson [19]. Validity was classified in descending order: Excellent $(\geq 0.60)$, Adequate (0. 59-0.31), and Low $(\leq 0.31)$. The data given in the Table were extracted from a study performed in the Czech Republic and complemented by the meta-analysis of Mortenson and Miller [17].

The content characteristic (Table 2) was constructed from the meta-analysis of the mentioned authors in 


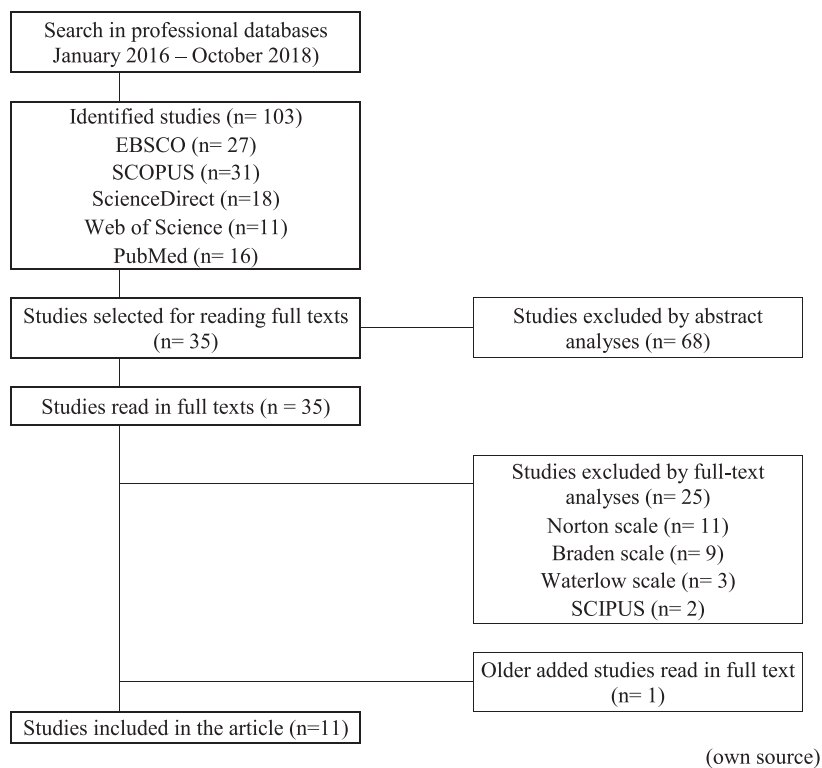

Fig. 1. Criteria for the selection of publications

combination with the primary sources of the Norton scale [20], Braden scale [21], Waterlow scale [22] and SCIPUS [16].

\section{RESULTS}

\section{Pressure ulcer risk assessment with the Norton scale}

In the Czech Republic, this scale started to be widely used as late as the 1990s. The last modification was registered in 1989 and consisted mainly of enrichment of the scoring with a verbal classification of each item as an illustration of health status. In addition, the assessed areas were extended - the original number of five was increased to be seven: physical condition, mental condition, physical activity, mobility, food intake, fluid intake, and incontinence [23]. The modification was a great benefit for nursing, as it brought theoretical information on additional risk factors. The scale was translated into several world languages, including Spanish [24], and is particularly focused care of the elderly [25].

The Norton scale is still used in some countries although a more recent scale is recommended for clinical practice. It continues to be used for research purposes and can be used in various areas, e.g. assessing the relation between the zinc level and pressure ulcer development [26], for a rapid assessment in emergency care [27], in operating rooms [28], in intensive care [29] in burns centres [30], etc.

The scale's sensitivity and specificity were studied in many countries and for many specialities; e.g. De Gouveia Santos et al. [31] mentioned the generally recognized specificity of the Norton scale as $65 \%$ and its sensitivity as $66 \%$ [32]. This was confirmed in the study by Šáteková et al., who mentioned a specificity of $59.81 \%$ and a sensitivity of $62.5 \%$ for the Czech population [14], and a specificity of $48.83 \%$ and the sensitivity of $85.71 \%$ for the Slovak population [32].

Many professionals evaluate the Norton scale and its modification as outdated. Thus, is it possible to perform studies with it or apply it in another way?

López et al. [33] repeated a study from 2005 and applied the modified Norton scale to modern nursing. They were focused on the correlation between the fulfilment of the need to eat and drink and the risk of developing pressure ulcers. The study included 219 patients at a surgical unit in whom pressure ulcers at any stages were present. Demographic factors were also included to make the study more specific while a new risk factor was revealed - sex. According to the study, women are at a higher risk than men - by as much as $17 \%$. The necessity of an individual assessment using quite a lot of deduction and guessing is emphasized. If a patient with some restrictive measures is to be assessed, the patient is automatically at risk and is not self-sufficient. The total assessment is finally very distorted and imprecise. For modern nursing, the authors recommend using a more recent scale which would register more areas.

A team of authors [34], studied the use of the Norton scale with 302 patients from another point of view, namely as a mortality predictor in a 1-month or 1-year cycle. Ten patients died during the one-month cycle, and 42 died during the 1-year cycle. The non-traditional use of the scale suggests new possibilities of application, though not as a mortality indicator. This scale is still sufficiently usable for research purposes, and it is agreed that in clinical practice it reflects some affected areas of the assessed patients. Nurses need not strictly monitor just the risk of pressure ulcers, but they can apply their skills to deal with the causes of the affected areas and, as a result, to prevent the ulcers.

Similarly, Ena [35] focused her research on the scale's use to determine the mortality in patients, among others,

Table 1. Assessment of the selected scales

\begin{tabular}{lcccc}
\hline Scale & Reliability & Sensitivity (\%) & Specificity (\%) & Validity \\
\hline $\begin{array}{l}\text { Pressure ulcer assessment according to } \\
\quad \text { Norton scale }\end{array}$ & $0.859-0.931$ & 62.50 & 59.81 & Low \\
$\begin{array}{l}\text { Pressure ulcer assessment according to } \\
\quad \text { Braden scale }\end{array}$ & $0.645-0.846$ & 70.09 & 50 & Adequate \\
$\begin{array}{l}\text { Pressure ulcer assessment according to } \\
\quad \text { Waterlow scale }\end{array}$ & $0.497-1.000$ & 100 & 18.69 & Adequate \\
$\begin{array}{l}\text { SCIPUS (Spinal Cord Injury Pressure } \\
\quad \text { Ulcer Scale) }\end{array}$ & Not given & 75.6 & 74 & Excellent \\
\hline
\end{tabular}

Sources: [14, 17]. 
Table 2. Characteristics of the content of the selected scales

\begin{tabular}{|c|c|c|c|c|c|}
\hline Scale & $\begin{array}{l}\text { Author (year of } \\
\text { publication) }\end{array}$ & $\begin{array}{l}\text { Number of } \\
\text { domains }\end{array}$ & Assessed areas & $\begin{array}{l}\text { Demanded } \\
\text { time }\end{array}$ & $\begin{array}{l}\text { Score }(\min / \\
\max )\end{array}$ \\
\hline $\begin{array}{l}\text { Pressure ulcer assessment } \\
\text { according to Norton scale }\end{array}$ & $\begin{array}{l}\text { Doreen Norton } \\
\quad(1962)\end{array}$ & 5 & $\begin{array}{c}\text { Physical condition } \\
\text { Mental condition } \\
\text { Activity } \\
\text { Mobility } \\
\text { Incontinence }\end{array}$ & $3-5 \min$ & $5 / 20$ \\
\hline $\begin{array}{l}\text { Pressure ulcer assessment } \\
\text { according to Braden scale }\end{array}$ & $\begin{array}{c}\text { Barbara Braden } \\
\quad(1987)\end{array}$ & 6 & $\begin{array}{c}\text { Perception } \\
\text { Moisture } \\
\text { Activity } \\
\text { Mobility } \\
\text { Nutrition } \\
\text { Friction and pressure }\end{array}$ & $3-5 \min$ & $6 / 23$ \\
\hline $\begin{array}{l}\text { Pressure ulcer assessment } \\
\text { according to Waterlow scale }\end{array}$ & Judy Waterlow (1985) & 8 & $\begin{array}{c}\text { Age } \\
\text { Sex } \\
\text { Build } \\
\text { Skin type } \\
\text { Appetite } \\
\text { Incontinence } \\
\text { Mobility } \\
\text { Special risks }\end{array}$ & $5-7 \mathrm{~min}$ & $3 / 45$ \\
\hline $\begin{array}{l}\text { SCIPUS (Spinal Cord Injury } \\
\text { Pressure Ulcer Scale) }\end{array}$ & $\begin{array}{c}\text { Andrew Salzberg } \\
\text { (1996) }\end{array}$ & 7 & $\begin{array}{c}\text { Activity } \\
\text { Mobility } \\
\text { Degree of the spinal cord } \\
\text { damage Incontinence/ } \\
\text { moisture } \\
\text { Concomitant diseases } \\
\text { Age } \\
\text { Smoking } \\
\text { Blood tests } \\
\text { Cognitive functions } \\
\text { Address }\end{array}$ & $5-15 \min$ & $0 / 25$ \\
\hline
\end{tabular}

Sources: $[16,20-22]$.

patients with the amputation of a lower extremity. Her study included 714 hospitalized patients studied for one year. The study results support the opinions of Robkowitz et al. [34] and encourage nursing professionals to use the scales for assessment of other non-standard risks. It is recommended to observe the assessed risks and show the improvements or impairments in individual areas separately. As an example, fall risks or indicators of effective rehabilitation after a serious surgery where the patient is partly or completely immobile can be mentioned. According to the author, the scale can also be used for revealing accompanying factors which can be indicators for the beginning of early palliative care, which can improve a long part of patient life in the terminal stage. In the Czech Republic, no studies focused on similar problems have been performed. However, a nonstandard scale application to healthcare could be very contributive. At least, a five-point scale could draw attention to a risk area which would be observed more carefully.

\section{Pressure ulcer risk assessment with the Braden scale}

The Braden scale was developed in 1987 in connection with the innovation, optimization, and enlargement of the theoretical basis of preventive measures, identifiable risks, and current possibilities of assessing the risk of pressure ulcers [36]. The data on the assessment scale was first published by Braden and Bergstrom in 1987. In the publication, the risk factors were analysed, and a new assessment outline called Pressure Sore Development (PSD) was described [21]. The assessment was divided into categories containing partial factors. In the original sounding, the PSD contained the categories of Pressure and Tissue Tolerance. The authors supposed that for pressure ulcer assessment in physically handicapped patients, the pressure ulcer incidence could be reduced to a minimum. In the study, the incidence of pressure ulcers was revealed as 4 out of 6 patients with hemiplegia, 0 out of 6 patients with paraplegia, and 0 out of 9 patients with quadriplegia when they were continuously assessed by the Braden scale. This scale is currently one of the most commonly used and has been translated into several world languages, including Spanish [37] and Chinese [38].

Currently, the Braden scale is used for the assessment of patients with physical handicaps [39], in traumatology [40], paediatrics [41], and palliative home care [42]. Lima-Serrano et al. state that the Braden scale has a specificity of $64 \%$ and a sensitivity of $83 \%$ [43]. These percentages are greater than those stated by Śáteková et al. who state specificity of $50 \%$ 
and a sensitivity of $70.09 \%$ for the Czech population [14], and a specificity of $53.48 \%$ and a sensitivity of $85.71 \%$ for the Slovak population [32].

Griswold et al. [44] studied the incidence of pressure ulcers in trauma patients and patients with burns who had a partial or complete physical handicap in the period between 2011 and 2014. Braden assessments were performed for 2,660 patients at traumatological ICUs and burn ICUs. Results with a value below 18 showed $100 \%$ sensitivity, but only 65 specificities. Results with a value below 9, showed 28.6 sensitivity and 90\% specificity. These results show that the Braden scale is not sufficiently prospective for use at traumatological and burn units. Undoubtedly, it can be used in standard units and in internal, surgical, or neurological ICUs. However, units with a more specific focus need a scale with a higher number of assessed areas. Logically, at the mentioned units, there are patients who are fully immobile and have various defects of skin, muscles, bones etc. Therefore, nursing care is much more intensive, and the risks of pressure ulcers are much higher. Similarly, it can be supposed that the same problems will occur at psychiatric units where restrictive measures are taken and at other units where patients show risk behaviours or are in a critical state.

Karahan et al. [45] used the Braden scale to draw attention to the importance of pressure ulcer incidence as an indicator of the quality of nursing care. Preventive measures were emphasized, but it was noted that all pressure ulcers cannot be eliminated, especially in physically handicapped patients. Age is one of the factors which cannot be influenced, for with increasing age, mobility is decreased, and if patients become fully immobile, the risk of pressure ulcers dramatically increases. Another extremely problematic area was emphasized - the existing pressure ulcer and its stage. In many cases, nurses deal only with the existing ulcer and do not remove the primary cause. Attention was also drawn to an extremely difficult treatment of pressure ulcers in physically handicapped patients, where the later stage of a pressure ulcer decreases the effectiveness of the treatment. This was documented by Karahan's results: a mere $23 \%$ of the pressure ulcers in handicapped patients were cured during the 8-week monitored time. The study revealed possibly important accompanying factors, particularly: sex, wound location, length of hospitalization, and concomitant diagnoses.

Based on the available sources, can it be stated that the Braden assessment scale is sufficiently effective for physically handicapped patients?

Fazel et al. [46] studied the incidence of pressure ulcers in patients after a transversal spinal cord lesion resulting in a permanent physical handicap. In 163 of 580 studied patients, a prevalence of $28.1 \%$, pressure ulcers were registered during the time of the study. From a long-term perspective, the Braden scale can be considered effective, but it must be used in a department of chronic diseases, e.g., a follow-up care unit, a rehabilitation unit, etc. This type of assessment score can be, and actually is, used in healthcare facilities. For physical handicaps, a modification of the scale, or another assessment scale containing more attributes relating to the physical handicap, is recommended.

\section{Pressure ulcer risk assessment with the Waterlow scale}

The Waterlow scale was developed in the UK where it is used very frequently. Assessments of Body Mass Index (BMI), age, and sex represent an advantage of this scale and provide data which can be processed statistically [31]. Currently, the scale is used for terminal or dementia patients [47], brain-stroke patients [48], patients in surgical, traumatological, or orthopaedic units [49], patients in community nursing [50], or in psychometric testing [51].

O'Brien et al. [52] studied the scale's sensitivity in a sample of 47 patients. The results showed a sensitivity of $100 \%$ and a specificity of $83 \%$. This partly confirmed the results of Šáteková et al., [14] in the Czech population, where the sensitivity was $100 \%$; however, the specificity was only $18.69 \%$. The same team found a sensitivity of $85.71 \%$ and a specificity $30.23 \%$ for the Slovak population [32].

Charalambou et al. [53] performed a literature search to study the validity of the Waterlow scale for physically handicapped patients. As other authors, they recognized the advantage of assessing age and sex. The scale is warmly recommended for clinical use since it is very user friendly. Since this scale is regarded as one of the most up-to-date and contains a wider spectrum of variables, could it be also used with physically handicapped patients?

This question was studied by de Azevedo Macena et al. [54], who also included several patients with respiratory diseases, cancer or renal failure, or sepsis in a study they performed in 19 healthcare facilities in Brazil. The data were collected using the Braden and Norton scales. From the results, a general level of the pressure ulcer assessment could be observed, for which the Waterlow scale is suitably constructed. For its application to cases such as a physical handicap, it does not seem to be suitable; however, a great advantage can be seen in its socio-demographic data, which make the statistical evaluation easier. A modification including a wider spectrum of variables, specifically, smoking, age, and the presence of diabetes mellitus or hypertension is recommended. The scale is suitable even in the original version, but a modification for use with physically handicapped patients is recommended.

The Waterlow scale is used in clinical practice but also in research, as the original version contains data like age and sex. These provide a possibility of measuring the incidence and prevalence in the population.

Smith et al. [55] measured pressure ulcer prevalence in the Australian population using the Waterlow scale. Their analysis included 1,407 participants from 2008, 1,331 participants from 2010, to 1,199 participants from 2014. Between 2008 and 2014, the number of inpatients with pressure ulcers dropped by $15.7 \%$. This drop was supposed to be caused by an improvement in the registration of risk factors and pressure ulcers and the complex assessment of risk factors. Though it is recommended to implement assessment scales in clinical practice, it is still the most important thing to observe preventive measures and keep in mind the human factor when providing professional nursing care. 


\section{Pressure ulcer risk assessment with the Spinal Cord Injury Pressure Ulcer Scale (SCIPUS)}

Spinal Cord Injury Pressure Ulcers Scale (SCIPUS) is one of the latest assessment scales. It is focused on known risk factors and enriched by blood tests measuring nutrition (albumin, creatine, and glycaemia) [17]. During the development of SCIPUS, several factors included in the scale were separated by continuous studying of published sources [56]. It is one of the most focused scales assessing added factors such as smoking, decreased albumin level, impaired mobility, sleeping pills, and presence of diabetes [57].

The specifically focused SCIPUS scale registers more risk factors than the Norton scale, making it more demanding and time-consuming for both nurse and patient. With this in mind, should it be used in standard units or in those with chronic or rehabilitation patients?

Krishnan et al. [58] studied the scale's use in emergencycare and rehabilitation-care units. The whole study was divided into 2-3-day and 5-7-day segments in emergency care and 5-7-day segments and 14-21-day segments in rehabilitation care. The results showed a precise assessment in the area of emergency care, with a sensitivity of $100 \%$ and a specificity of $75 \%$. With increased hospitalization time, the scale's values decrease. It is recommended to implement SCIPUS in modern nursing, particularly in emergency care and for a short-term assessment of physically handicapped patients. For standard units, other scales, which are less time-consuming and demand fewer invasive interventions, are recommended.

Thus, SCIPUS could be implemented in specifically focused units where fully immobile or physically handicapped patients are treated. These could include anaesthesiology-resuscitation units, some kinds of ICUs, spinal units, etc. According to some studies, SCIPUS could also be used in emergency-admitted patients who will be hospitalized, and in whom an invasive blood collection is performed. Would nursing care be better if the present assessment scales were replaced by this updated scale?

In comparison with the Braden, Gosnell, Norton, and Waterlow scales, it was discovered that SCIPUS provides more complex data. However, these extensive data are not suitable for chronically ill patients, since the invasive interventions might be burdening for them. SCIPUS is therefore not recommended for units with chronically ill patients, but it is suitable for units providing emergency care. It is highly probable that studies of the SCIPUS scale will be also implemented for the Czech population, where slight modifications could be performed. Modification of the general SCIPUS would be welcomed, particularly in units focused on immobile and physically handicapped patients [17].

\section{DISCUSSION AND CONCLUSIONS}

Assessment of pressure ulcers is not only one of the indicators of nursing care quality but also a burden for the patient and a complication for the nurse. Pressure ulcers can be prevented, but due to the neuropathy and incontinence associated with paresis and paralysis, the risk of pressure ulcers is increased, and the effectiveness of the preventive measures decreased. Using a suitable assessment scale, the risk factors can be recognized and, as a result, the risk minimized. The Braden, Waterlow, and Norton scales for pressure ulcer risk assessment are used for assessment at a general level. The more recent SCIPUS scale is suitable for emergency care and specific units such as spinal units, anaesthesiology-resuscitation units, or ICUs. The use of SCIPUS is the most appropriate in emergency care for a period of 1-5 days. In a longer interval, SCIPUS loses its assessment effectiveness and can be rather burdening for patients. Clinical professionals agree that two very important variables must not be forgotten - the human factor and human autonomy. If these virtually unmeasurable factors are neglected, patients are also put at risk for the development of pressure ulcers. It is, therefore, necessary for physically handicapped patients to be assessed more frequently, and for nurses to more carefully observe basic preventive measures such as positioning and hygiene. By accepting more modern assessment scales such as SCIPUS, the quality of nursing care can be improved and the incidence of pressure ulcers reduced. A study focused on the use of SCIPUS in the Czech population should be implemented.

Ethical approval: The professional article was processed in accordance with the Helsinki Declaration, the Ethical Code and internal regulations.

Authors' contribution: JN the Author and VT the Co-author (equal contribution), summarized the scientific background of the paper, prepared and revised of the manuscript and finalized the text.

Conflict of interest/funding: The authors declare no conflict of interest. This study has been supported by purpose-bound Research \& Development finances of the Faculty of Health and Social Sciences, the University of South Bohemia in Ceske Budejovice, No. 058/2018/S.

Acknowledgements: The article relates to the GAJU 058/ 2018/S research project, which was implemented under the financial support of GAJU and is taking place at the Faculty of Health and Social Sciences of the University of South Bohemia in České Budějovice.

\section{REFERENCES}

1. Hanková M, Vávrová S. Partnerské vztahy: očima mladých dospělých s vrozeným tělesným postižením [Partnerships: through the eyes of young adults with congenital physical disabilities]. Praha: Grada; 2016. [Book in Czech].

2. Čírtková L, Vitoušová P. Pomoc obětem (a svědkům) trestných činů: príručka pro pomáhající profese [Assistance to crime victims (and witnesses): a handbook for helping professions]. Praha: Grada; 2007. [Book in Czech]. 
3. Kočová H. Spinální svalová atrofie v souvislostech [Spinal muscular atrophy in context]. Praha: Grada Publishing; 2017. [Book in Czech].

4. Opatřilová $\mathrm{D}$, Zámečníková $\mathrm{D}$. Somatopedie: texty $\mathrm{k}$ distančnímu vzdělávání [Somatopaedia: texts on distance education]. Brno: Paido; 2007. [Book in Czech].

5. Novosad L. Poradenství pro osoby se zdravotním a sociálním znevýhodněním [Counselling for persons with health and social disadvantages]. Praha: Portál; 2009. [Book in Czech].

6. Bibi S, Rasmussen P, McLiesh P. The lived experience: nurses' experience of caring for patients with a traumatic spinal cord injury. Int J Orthop Trauma Nurs 2018;30(1):31-8. https://doi.org/ 10.1016/j.ijotn.2018.05.002.

7. Brienza D, Krishnan S, Karg PE, Sowa GA, Allegretti AL. Predictors of pressure ulcer incidence following traumatic spinal cord injury: a secondary analysis of a prospective longitudinal study. Spinal Cord 2017;56(1):28-34. https://doi.org/10.1038/sc.2017.96.

8. Krishnan S, Karg PE, Boninger ML, Brienza DM. Association between presence of pneumonia and pressure ulcer formation following traumatic spinal cord injury. J Spinal Cord Med 2017; 40(4):415-22. https://doi.org/10.1080/10790268.2016.1180099.

9. Joseph C, Nilsson Wikmar L. Prevalence of secondary medical complication and risk factors for pressure ulcers after traumatic spinal cord injury during acute care in South Africa. Spinal Cord 2016;54(7):535-9. https://doi.org/10.1038/sc.2015.189.

10. Kučírek J. Aplikovaná psychologie: vybraná témata: teleworking, leadership, sociálně psychologický výcvik [Applied psychology: selected topics: Teleworking, leadership, socio-psychological training]. Praha: Grada; 2017. [Book in Czech].

11. Slowík J. Speciální pedagogika [Special education]. 2nd ed. Praha: Grada; 2016. [Book in Czech].

12. Weber J, Kelley J. Health assessment in nursing. 6th ed. Philadelphia: Wolters Kluwer; 2018.

13. Šáteková L, Žiaková K. Inter-rater reliability of items of the Braden scale, the Norton scale and Waterlow scale. PROFESE Online 2016; 9(2):10-5. Available from: https://www.profeseonline.upol.cz/en/ pdfs/pol/2016/02/02.pdf.

14. Šáteková L, Žiaková K, Zeleníková R. Predictive validity of the Braden Scale, Norton Scale, and Waterlow Scale in the Czech Republic. Int J Nurs Pract 2017;23(1). https://doi.org/10.1111/ijn. 12499.

15. Duruflé A, Mathieu L, Robineau S, Nicolas B, Leblong E, Fraudet B, et al. Evaluation of the impact of a therapeutic educational program concerning the prevention of risk of pressure ulcers for persons with a spinal cord lesion. Ann Phys Rehabil Med 2018;61:384. https://doi.org/10.1016/j.rehab.2018.05.894.

16. Salzberg CA, Byrne DW, Cayten CG, van Niewerburgh P, Murphy JG, Viehbeck M. A new pressure ulcer risk assessment scale for individuals with spinal cord injury. Am J Phys Med Rehabil 1996; 75(2):96-104.

17. Mortenson WB, Miller WC. A review of scales for assessing the risk of developing a pressure ulcer in individuals with SCI. Spinal Cord 2008;46(3):168-75.

18. Krishnan S, Brick RS, Karg PE, Tzen YT, Garber SL, Sowa GA, et al. Predictive validity of the Spinal Cord Injury Pressure Ulcer Scale (SCIPUS) in acute care and inpatient rehabilitation in individuals with traumatic spinal cord injury. NeuroRehabilitation 2016;38(4): 401-9. https://doi.org/10.3233/NRE-161331.
19. Andresen EM. Criteria for assessing the tools of disability outcomes research. Arch Phys Med Rehabil 2000;81(12 Suppl. 2):S15-20.

20. Norton D, McLaren R, Livingstone C. An investigation of geriatric nursing problems in hospital. New York: Churchill Livingstone; 1975.

21. Braden B, Bergstrom N. A conceptual schema for the study of the etiology of pressure sores. Rehabil Nurs 1987;12(1):8-12.

22. Waterlow J. Pressure sores: a risk assessment card. Nurs Times 1985;81(48):49-55.

23. Mikula J, Müllerová M. Prevence dekubitů [Prevention of pressure sores]. 1. vydání. Praha:Grada; 2008. [Book in Czech].

24. Pancorbo-Hidalgo PL, Torra-Bou JE, García-Fernández FP, Soldevilla Agreda JJ. Prevalence of pressure injuries and other dependence-related skin lesion among paediatric patients in hospitals in Spain. EWMA J 2018;19(2):29-37.

25. Park SH, Lee HS. Assessing predictive validity of pressure ulcer risk scales - a systematic review and meta-analysis. Iran J Public Health 2016;45(2):122-33.

26. Rivas-García TE, Marcelo-Pons M, Martínez-Arnau F, Serra-Catalá N, Santamaría-Carrillo Y, Cauli O. Blood zinc levels and cognitive and functional evaluation in non-demented older patients. Exp Gerontol 2018;108:28-34. https://doi.org/10.1016/j.exger.2018.03. 003.

27. Shi C, Dumville JC, Cullum N. Evaluating the development and validation of empirically-derived prognostic models for pressure ulcer risk assessment: a systematic review. Int J Nurs Stud 2019;89: 88-103. https://doi.org/10.1016/j.ijnurstu.2018.08.005.

28. Li TG. Reliability and validity Munro Scale on the assessment of pressure ulcer risks in adult perioperative patients: a cross-sectional study. Int J Clin Exp Med 2018;11(9): 9811-8.

29. Lospitao-Gómez S, Sebastián-Viana T, Gonzáles-Ruíz JM, ÁlvarezRodrdríguez J. Validity of the current risk assessment scale for pressure ulcers in intensive care (EVARUCI) and the Norton-MI scale in critically ill patients. Appl Nurs Res 2017;38:76-82. https:// doi.org/10.1016/j.apnr.2017.09.004.

30. Lerma V, Macías M, Toro R, Moscoso A, Alonso Y, Hernández O, et al. Care in patients with epidermal necrolysis in burn units. A nursing perspective. Burns 2018;44(8):1962-72. https://doi.org/10. 1016/j.burns.2018.06.010.

31. De Gouveia Santos VLC, Faria Serpa L, Lobo Cordero GM, Guererro Gamboa S. Risk assessment in pressure ulcers. Science and practice of pressure ulcer management. London: Springer London; 2018.

32. Šáteková L, Žiaková K. Zeleníková R. Predictive validity of the Braden scale, Norton scale and Waterlow scale in Slovak Republic. CEJNM 2015;6(3):283-90. https://doi.org/10.15452/CEJNM.2015.06.0017.

33. López M, Jiménez JM, Fernández M, Martín B, Cao MJ, Castro MJ. Relationship between pressure ulcer risk based on Norton Scale and on the "Eating/Drinking" need assessment. J Nurs Manag 2019; 27(1):117-24. https://doi.org/10.1111/jonm.12655.

34. Rabinovitz E, Finkelstein A, Ben Assa E, Steinvil A, Konigstein M, Shacham Y, et al. Norton scale for predicting prognosis in elderly patients undergoing trans-catheter aortic valve implantation: a historical prospective study. J Cardiol 2016;67(6):519-25. https:// doi.org/10.1016/j.jjcc.2016.01.017.

35. Ena J. Norton scale and vital prognosis. Revista Clínica Espaňola (English Edition) 2018; 218(4):185-6. https://doi.org/10.1016/j. rceng.2018.02.005. 
36. Gážiová M. Jednotný postup proti dekubitom [Uniform action against pressure sores]. Sestra 2013;12(1-2):12-4. [Article in Slovak]. Available from: http://spupa.sk/wp-content/uploads/2013/ 11/1-Jednotny-postup-proti-dekubitom.pdf.

37. García-Molina P, Balaguer López E, Verdú J, Nolasco A, García Fernández FP. Cross-cultural adaptation, reliability and validity of the Spanish version of the Neonatal Skin Risk Assessment Scale. J Nurs Manag 2018;26(6):744-56. https://doi.org/10.1111/jonm.12612.

38. Chen HL, Zhu B, Wei R, Zhou ZY. A retrospective analysis to evaluate seasonal pressure injury incidence differences among hip fracture patients in a Tertiary Hospital in East China. Ostomy Wound Managet 2018;64(2):40-4.

39. Sturgill B, Patolia H, Gushiken A, Gomez Dela Espriella M, BaffoeBonnie AW. Braden score may be associated with time to onset of catheter-associated urinary tract infection in high-risk patients: Lessons learned from a root cause analysis tool. Am J Infect Control 2019;47(3):343-5. https://doi.org/10.1016/j.ajic.2018.09.002.

40. Grigorian A, Sugimoto M, Joe V, Schubl S, Lekawa M, Dolich M, et al. Pressure ulcer in trauma patients: a higher spinal cord injury level leads to higher risk. J Am Coll Clin Wound Spec 2018;9(1-3): 24-31. https://doi.org/10.1016/j.jccw.2018.06.001.

41. Curley MAQ, Hasbani NR, Quigley SM, Stellar JJ, Pasek TA, Shelley SS, et al. Predicting pressure injury risk in pediatric patients: the braden QD scale. J Pediatr 2018;192:189-95. https://doi.org/10. 1016/j.jpeds.2017.09.045.

42. Articio M, Dante A, D'angelo D, Lamarca L, Mastroianni C, Petitti $\mathrm{T}$, et al. Prevalence, incidence and associated factors of pressure ulcers in home palliative care patients: a retrospective chart review. Palliat Med 2017;32(1):299-307. https://doi.org/10.1177/ 0269216317737671.

43. Lima-Serrano M, González-Méndez MI, Martín-Casta ño C, Alonso-Araujo I, Lima-Rodríguez JS. Predictive validity and reliability of the Braden scale for risk assessment of pressure ulcers in an intensive care unit. Med Intensiva [Article in English, Spanish] 2018;42(2): 82-91. https://doi.org/10.1016/j.medin.2016.12.014.

44. Griswold LH, Griffin RL, Swain T, Kerby JD. Validity of the Braden Scale in grading pressure ulcers in trauma and burn patients. J Surg Res 2017;219:151-7. https://doi.org/10.1016/j.jss.2017.05.095.

45. Karahan A, Abbasoglu A, Işık SA, Çevik B, Saltan Ç, Elbaş NÖ, et al. Factors affecting wound healing in individuals with pressure ulcers: a retrospective study. Ostomy Wound Manage 2018;64(2):32-9.

46. Fazel FS, Derakhshanrad N, Yakeninejad MS, Vosoughi F, Derakhshanrad A, Saberi H. Predictive value of braden risk factors in pressure ulcers of outpatients with spinal cord injury. Acta Med Iran 2018;56(1):56-61.

47. Sampson EL, Candy B, Davis S, Gola AB, Harrington J, King M, et al. Living and dying with advanced dementia: a prospective cohort study of symptoms, service use and care at the end of life. Palliat Med 2017;32(3):668-81. https://doi.org/10.1177/ 0269216317726443 .
48. Chitambira B, Evans S. Repositioning stroke patients with pusher syndrome to reduce incidence of pressure ulcers. Brit J Neurosci Nurs 2018;14(1):16-21. https://doi.org/10.12968/bjnn.2018.14.1. 16.

49. Hekmaptou D, Mehrabi F, Rahzani K, Aminiyan A. The effect of Aloe Vera gel on prevention of pressure ulcers in patients hospitalized in the orthopedic wards: a randomized triple-blind clinical trial. BMC Complement Altern Med 2018;18(1):264. https://doi. org/10.1186/s12906-018-2326-2.

50. Nazarko L. Prevention of pressure ulcers in community care settings. [Internet]. London: Independent Nurse; 2018 July [cited 2019 May 25]. Available from: https://www.independentnurse.co.uk/ clinical-article/prevention-of-pressure-ulcers-in-community-caresettings/176273/.

51. Porcel-Gálvez AM, Romero-Castillo R, Fernández-García E, Barrientos-Trigo S. Psychometric testing of INTEGRARE, an instrument for the assesment of pressure ulcer risk in inpatients. Int $J$ Nurs Knowl 2018;29(3):165-70. https://doi.org/10.1111/2047-3095. 12173.

52. O'Brien G, Moore Z, Patton D, O'Connor T. The relationship between nurses assessment of early pressure ulcer damage and sub epidermal moisture measurement: a prospective explorative study. J Tissue Viability 2018;27(4):232-7. https://doi.org/10.1016/j.jtv. 2018.06.004.

53. Charalambous C, Koulori A, Vasilopouos A, Roupa Z. Evaluation of the validity and reliability of the waterlow pressure ulcer risk assessment scale. Med Arch 2018;72(2):141-4. https://doi.org/10. 5455/medarh.2018.72.141-144.

54. de Azevedo Macena MS, da Costa Silva RS, Dias Fernandes MIDC, de Almeida Medeiros AB, Batista Lúcio KD, de Carvalho Lira ALB. Pressure ulcer risk evaluation in critical patients: clinical and social characteristics. Open Nurs J 2017;11:91-7. https://doi.org/10.2174/ 1874434601711010091.

55. Smith SK, Ashby SE, Thomas L, Williams F. Evaluation of a multifactorial approach to reduce the prevalence of pressure injuries in regional Australian acute inpatient care settings. Int Wound J 2018;15(1):95-105. https://doi.org/10.1111/iwj.12840.

56. Krause JS, Vines CL, Farley TL, Sniezek J, Coker J. An exploratory study of pressure ulcers after spinal cord injury: relationship to protective behaviors and risk factors. Arch Phys Med Rehabil 2001; 82(1):107-13.

57. Krause JS, Broderick L. Patterns of recurrent pressure ulcers after spinal cord injury: identification of risk and protective factors 5 or more years after onset. Arch Phys Med Rehabil 2004;85(8): 1257-64.

58. Krishan S, Brick RS, Karg PE, Tzen YT, Garber SL, Sowa GA, et al. Predictive validity of the Spinal Cord Injury Pressure Ulcer Scale (SCIPUS) in acute care and inpatient rehabilitation in individuals with traumatic spinal cord injury. NeuroRehabilitation 2016;38(4): 401-9. https://doi.org/10.3233/NRE-161331.

Open Access statement. This is an open-access article distributed under the terms of the Creative Commons Attribution-NonCommercial 4.0 International License (https:// creativecommons.org/licenses/by-nc/4.0/), which permits unrestricted use, distribution, and reproduction in any medium for non-commercial purposes, provided the original author and source are credited, a link to the CC License is provided, and changes - if any - are indicated. 